Jurnal MAKSIPRENEUR, Vol. I, No. 1, 2011, hal. 21-37

\title{
KEADILAN DISTRIBUTIF KOPERASI
}

\author{
Suroto \\ Lembaga Studi Pengembangan \\ Perkoperasian Indonesia ( LSP2I), Jakarta
}

\begin{abstract}
Many theories of development rely solely on growth and ignore factors of wealth distribution. It was shown of how to cope with poverty, which is often solved by good old-fashioned form of creating the job, but the question of his groundbreaking discoveries ignored, where poverty is not only concerned about employment, but also with regard to the question creatingwealth. This article mean to elaborate three models of economic system, differentiated into capitalistic model, communistic model, and cooperative model, where the cooperative model is more democratic and participatory.
\end{abstract}

Key Words: Cooperative, Justice, Economic Democracy

\section{PENDAHULUAN}

Pembangunan merupakan upaya terus menerus untuk memperbaiki kondisi agar menjadi lebih baik. Namun seringkali, terutama di negara berkembang, dalam pencapaian pembangunan muncul persoalan baru berupa disparitas sosial-ekonomi, dimana pencapaian pertumbuhan ekonomi di satu sisi telah digayuti oleh ketidakmerataan ekonomi di sisi yang lain. Angka-angka agregat pertumbuhan ekonomi yang mencengangkan seringkali tidak menggambarkan realitas sosial masyarakat. Ketimpangan distribusi pendapatan atau kekayaan antara orang yang kaya dengan yang hidup di bawah garis kemiskinan terjadi semakin lebar.

Akhir-akhir ini kita semua disodori fakta bahwa sistem ekonomi Amerika Serikat yang hanya memberikan prioritas pada segelentir orang sedang menuai protes keras oleh sebuah aksi massif bertajuk Occupy Wall Street 1\%/99\%, dan kita juga melihat bahwa sistem dominasi negara yang digambarkan keberhasilanya oleh Cina saat ini juga masih berada dalam tanda tanya besar dalam hal persoalan keadilan dan keberlangsunganya. Sementara sistem negara kesejahteraan sebagai varian yang lain dari negara-negara Skandinavia mengalami gejala penurunan produktivitas karena peran negara yang terlalu kaku dalam distribusi kesejahteraannya. 
Pertumbuhan ekonomi yang abai terhadap keadilan pada akhirnya selalu menyajikan kondisi diametral terhadap realitas sosial-ekonomi masyarakat. Keadilan hanya menjadi jargon pembangunan semata-mata. Realitas sehari-hari adalah kehidupan yang mencekik, sulitnya mendapatkan pekerjaan, pendidikan yang semakin mahal, atau akses layanan kesehatan yang semakin memberatkan bagi kebanyakan orang. Dalam banyak strategi pembangunan yang mengandalkan pertumbuhan dan abai terhadap distribusinya, kemiskinan seringkali juga hanya diselesaikan dengan cara-cara kuno berupa penciptaan lapangan kerja baru (creating the job), tapi alpa terhadap persoalan mendasarnya yang berupa distribusi yang adil dalam pendapatan dan kekayaan. Padahal jelas, kemiskinan itu sama sekali bukan hanya menyangkut tidak adanya pekerjaan, tapi juga menyangkut persoalan mengkreasi kekayaan.

Ada tiga model penting dalam sistem penyelenggaraan ekonomi, pertama adalah model kapitalistik dengan dominasi pada pemilikan individu dan perusahaan swasta, kedua model komunistik dengan dominasi kepemilikan negara dan perusahaan publik, dan yang ketiga adalah model koperasi dengan kepemilikan model demokrasi partisipatorik masyarakat.

Koperasi sebagai sebuah sistem demokrasi ekonomi memiliki peran penting untuk mewujudkan keadilan ekonomi secara distributif tersebut karena melalui jalan koperasi setiap individu memiliki peluang yang sama untuk terlibat dalam proses produksi, konsumsi dan distribusinya. Praktik ini sebagaimana terlihat dalam manajemen koperasi produsen, koperasi konsumen, koperasi pekerja, koperasi kredit, koperasi layanan publik, koperasi-koperasi kreatif dan lain sebagainya.

\section{KAPITALISME GLOBAL DAN IDE PEMBAHARUAN SOSIAL}

Kapitalisme secara etimologi berasal dari kata dasar kapital, yang artinya modal. Sementara isme diartikan sebagai ajaran atau paham. Sehingga dapat didefinisikan sebagai suatu ajaran yang didasarkan pada basis modal (capital base). Mereka yang menempatkan modal sebagai penentu (master) dari sekedar arti modal sebagai pembantu (servant) disebut sebagai kaum kapitalis, penganut paham ini. Kapital (baca: modal finansial) yang tak terikat oleh nilai-nilai kemanusiaan menjadi sentrum dari setiap tindakan orang, pada akhirnya siapapun yang menjadi pemenang dalam kebebasan untuk mengakumulasi modal secara berlebihan menjadi penindas/menguasai orang lain. Kekuatan modal menjadi kuasa bagi orang dan modal berdiri di atas harkat dan martabat manusia.

Warner Sombart menyebut kapitalisme adalah sebuah sistem pemikiran ekonomi yang bersifat netral. Sebagai sistem pemikiran, kapitalisme ditandai oleh semangat tiga hal: pemilikan, persaingan dan rasionalitas. Sementara itu banyak pakar yang menganggap bahwa 
kapitalisme itu adalah sebuah sistem ekonomi atau sosial. Lebih sempit dari itu kapitalisme juga sering disebut sebagai "sistem industri modern". Tapi dari berbagai pendapat dapat disimpulkan bahwa kapitalisme adalah sebuah sistem ekonomi dengan dasar pemikiran bahwa modal adalah penentu di atas kepentingan kemanusiaan.

Sebagai sistem ekonomi, kapitalisme dicirikan oleh adanya kegiatan ekonomi dan kontrol keuangan oleh usaha-usaha besar milik pribadi, dalam arti orang seorang maupun keluarga, akumulasi laba sebesar-besarnya dalam motif pencarian keuntungan (profit oriented), ekonomi pasar persaingan dominan yang ditopang oleh konsumerisme, dan penentuan harga tenaga kerja yang mengikuti mekanisme pasar.

Kapitalisme dalam perkembangan peradaban seperti saat ini tentu tidak lagi sama seperti pada saat kapitalisme awal berkembang pada masa revolusi industri. Tapi perangai kapitalisme yang tidak berubah adalah model kuasa segelintir orang terhadap orang kebanyakan, dan modal dijadikan sebagai penentu ketimbang sebagai alat bantu, karena begitulah hukum yang berlaku dalam sistem kapitalisme. Sebagian kecil orang telah mendominasi dan berkuasa sementara sebagian besar yang lain dalam keadaan tersubordinasi dan termarginalisasi.

Dalam sistem ini, negara bertindak untuk melayani kepentingan pasar yang didominasi oleh para pemilik modal kapital besar. Negara menyokong investasi dan kredit, perlindungan tarif bagi importir, serta hak-hak istimewa. Kapitalisme dalam tahap akumulatif dapat menjaga stabilitas dan memperbesar belanja militer. Bagi negara-negara penganut paham "kapitalisme pinggiran", seperti Indonesia misalnya, seringkali karena pendapatan melebihi pengeluarannya, maka negara kemudian tak ubahnya sebuah mesin pencari utang.

Sistem kapitalisme global yang dibungkus rapi dalam topeng karitas tetap saja tak dapat menyembunyikan wajah buruk sejatinya. Fakta-fakta menunjukkan bahwa kapitalisme telah menyumbang persoalan berat seperti marginalisasi masyarakat kebanyakan dalam bentuk kemiskinan, pengangguran, dan kerusakan lingkungan. Joseph Stigliz (2007) menuliskan fakta-fakta nyata betapa globalisasi berjalan dalam kondisi yang tidak seimbang diantara negara-negara miskin dan kaya.

Korporasi Multinational (MNC) dan Korporasi Transnasional (TNC) yang ditopang oleh ideologi laissez faire berusaha memupuk modal akumulatif tanpa mempertimbangkan dampak-dampak sosial yang ditimbulkan. Kapitalisme memasang agensinya seperti IMF (International Monetery Fund), World Bank, World Trade Organization (WTO) untuk mengkampanyekan liberalisasi, deregulasi dan privatisasi. Melalui transaksi finansial spekulatif dan monopoli korporasi, kapitalisme telah menyajikan laju pertumbuhan yang asimetris terhadap persoalan kemanusian secara luas. 
Tata dunia saat ini adalah bentuk jejaring interdependensi umat manusia yang tidak lagi terikat oleh batas-batas teritori. Begitulah gambaran globalisasi tanpa batas teritori saat ini, yang oleh R.O. Keohane dan Joseph S. Nye (2000) dicirikan adanya keluasan (extencity), kekuatan (intencity), kecepatan (velocity) dan dampak (impact). Globalisasi memang bersifat multidimensional, namun demikian globalisasi ekonomi senantiasa tampil paling dominan karena globalisasi ekonomi memiliki dampak yang nyata dibandingkan dengan bentuk globalisasi non-ekonomi (Prakash dan Hart, 1999). Dalam sektor ekonomi, kita dihadapkan pada tantangan jangka panjang dunia yang semakin liberal dengan aktor utama Mutinational dan Transnational Corporation (TNC's/MNC's) serta lembaga-lembaga keuangan dan perdagangan dunia seperti IMF, World Bank, dan WTO yang merupakan anyaman yang sulur menyulur dari ekonomi global. Pasar bebas (free market) sebagai topangan hidup kepentingan dari kapitalisme mendikte segala bentuk kehidupan masyarakat, dan termasuk dalam kehidupan berbangsa dan bernegara.

Pembagian yang tidak adil ini terlihat dari disparitas sosial ekonomi yang semakin meningkat. Berdasarkan laporan PBB 1999 menunjukan bahwa $20 \%$ orang di negara maju menguasai $86 \%$ Produk Domestik Bruto dunia, menghasilkan $83 \%$ pasar ekspor dunia, $68 \%$ investasi asing dan $74 \%$ saluran telepon dunia. Rata-rata pendapatan perkapita orang-orang kaya pada tahun 1966 adalah 30 kali lipat dari pendapatan kelompok miskin. Pada tahun 1999 perbandingan tersebut menjadi 82 kali lipat. Di Indonesia sendiri, total peredaran uang $70 \%$ ada di Jakarta. Dari total peredaran uang tersebut, mayoritas dikuasai oleh tidak lebih dari 3,5\% penduduk Indonesia. Menurut Stiijt pada tahun 1999, 15 keluarga di Indonesia menguasai kekayaan republik ini hingga lebih dari 40\% (Stijt, 2003, Sunarko, 2005).

Tata baru dunia tidak saja ditandai dengan ketimpangan, pihak yang amat kaya para tuan modal kapital ini juga menghancurkan Negara sebagai agen distribusi kesejahteraan, Negara kesejahteraan dengan pola barunya didorong untuk menjamin masyarakat yang tergantung pada perusahaan kapitalis. Pendidikan, kesehatan dan lingkungan menjadi kapling baru kepentingan akumulasi modal kapital kapitalisme.

Bagi Indonesia sendiri, kelihatannya kecenderungan yang ada terlihat bahwa, setelah 32 tahun kita hidup di bawah sistem patron klien negarakapitalis (state-led capitalism), orientasi yang ada saat ini hanya mengarah pada sistem kapitalisme pasar (market-led capitalism). Kalau yang pertama kapitalisme bersekongkol dengan kekuasaan seorang despot, yang kita jalani saat ini sesunguhnya negara sendiri telah dibelengu oleh tuan kapitalis besar yang datang membawa kuasa uang. Ide-ide perubahan sosial yang mendamba dunia yang lain dan atau mencita akan dunia yang lebih baik memang sudah sering muncul. Dalam hal ini sengaja saya menyebutkan sebagian saja. Sebut saja seperti ide besar seperti sosialisme- 
marxisme, atau sekadar konsep penjinakan kapitalisme itu sendiri dalam model negara kesejahteraan.

Sosialisme-Marxisme menghendaki pemusatan kegiatan ekonomi, kontrol yang ketat pada pemilikan pribadi, memfungsikan negara sebagai mesin ideologi menuju transformasi pada sistem masyarakat tanpa kelas. Namun kita melihat kenyataan bahwa ide sosialisme-marxis tak mampu juga membuktikan dirinya sebagai kekuatan pengimbang. Banyak persoalan yang tak terpecahkan seperti tidak adanya konsep yang jelas dalam proses pemilikan perusahaan paska revolusi, dan proses membangun masyarakat yang dilandaskan pada konsep kesadaran hakiki, kecuali pengandalan pada mesin "kesadaran semu" yang mereka citakan. Sementara fakta sejarah menunjukkan juga bahwa di negara asalnya Eropa Timur, Rusia dan Yugoslavia, Rumania, revolusi sejatinya menuju masyarakat kelas ini juga tidak pernah kita lihat sebagai fakta empirikal yang meyakinkan.

Sementara sebagai konsep penjinakan kapitalisme, konsep negara kesejahteraan (welfare state) hanya menempatkan negara sebagai kontrol sosial dan promotor kesejahteraan agar pemiskinan tidak terjadi melalui berbagai produk perundang-undangan tentang jaminan sosial kesejahteraan warga negara. Atau teori Status Kewarganegaraan dengan institusionalisasi hak-hak warga negara di bidang politik ekonomi sosial dan budaya (poleksosbud), dimana kelompok borjuis dan kelas pekerja di integrasikan dalam masyarakat sipil dan kekuasaan dalam proyek "demokratisasi". Namun apa yang kita dapati bahwa karena dalam hal ini sejatinya kapitalisme tidak berubah substansinya maka yang muncul adalah justru imperialisme dalam bentuknya yang lain, negara-negara penganutnya seperti Eropa Barat dan Amerika Utara yang berubah wujud sebagai Kapitalisme Negara, dimana negara jadi instrumen modal dan perluasan pasar yang ditopang oleh penguasaan mereka terhadap organisasiorganisasi multinasional seperti IMF, World Bank dan WTO.

Sementara itu, ide dasar koperasi sebagai produk budaya eksistensinya tak dapat dilepaskan dari sejarah panjangnya sebagai sebuah gerakan perubahan sosial (social change movement) melawan pemerasan, kebodohan, kemiskinan, dominasi, persaingan bebas dan berbagai bentuk eksploitasi kemanusiaan lainnya. Adalah abad 18, abad ini dapat dikatakan sebagai abad perubahan sosial, ekonomi dan teknologi bagi negara-negara Eropa Barat (terutama Inggris Raya). Di dorong oleh lingkungan liberal yang terinpirasi dari gagasan Adam Smith dalam karyanya yang terkenal, An Inquiry into the Nature and Cause of the Wealth of Nations (1776), semangat kapitalisme feodal pada waktu itu tumbuh dengan subur. Dimana kebebasan individu dijamin seluas-luasnya bagi tujuan kemakmuran dalam semangat laizess faire. Kaum kapitalis yang sejak awal telah memiliki akses terhadap sumberdaya lebih banyak cenderung mempunyai kebebasan lebih banyak; sedangkan kaum buruh, petani dan perajin rumah tangga dalam 
kedudukan yang lemah. Sistem laizess faire ini telah mendatangkan kepincangan sosial dimana yang kaya makin kaya dan yang miskin makin tertindas.

Berangkat dari kondisi tersebut maka muncul gagasan-gagasan perubahan sosial utopis yang dimotori terutama oleh tokoh-tokoh sosialisme ortodhok seperti Proudhon, Robert Owen, Saint Simon, Carles Fourier, William King dan masih banyak lagi. Dalam gagasan yang berbedabeda tapi dalam suatu harapan adanya perwujudan suatu sistem yang menekankan pada sistem sosial yang hampir sama. Dimana sosial sebagai lawan dari egoisme, ko-operatif lawan kompetitif, kontrol-kontrol sosial yang ketat pada akumulasi dan pemakaian hak milik pribadi; dan persamaan ekonomi maupun setidaknya penghargaan menurut kebaikan umum. Pada masa munculnya sosialisme awal waktu itulah pemikiranpemikiran koperasi pertama muncul sebagai gerakan rakyat. Pergulatan wacana yang terjadi adalah merupakan proses pencarian bentuk antara ketidakpuasan dari praktek kapitalisme sebagai "kanan" dan marxis komunis sebagai "kiri" dalam tuntutan perubahan radikal revolusioner. Kekuatan kapitalisme feodal mendapat tentangan dari kekuatan marxiskomunis dalam manifesto politiknya. Kedua-duanya masih dalam wujudnya yang ortodok.

Perseteruan yang terjadi dari keduanya menimbulkan gejolak sosial yang mengakibatkan banyak kerusakan dimana-mana. Di tengah kegalauan rakyat yang terjadi, munculah pada waktu itu gerakan sosial-ekonomi sebagai alternatif yang disebut dengan koperasi, co-operative, atau co-op. Gerakan ini dalam banyak hal sama dengan tujuan kaum revolusioner, hanya dengan pengecualian tekanan perjuanganya ditekankan pada evolusi ketimbang revolusi (Munkner, 1995).

Koperasi atau Co-op sebagai organisasi modern pertama berdiri pada tahun 1844 oleh 28 orang buruh Pabrik tenun, tepatnya pada tanggal 22 Desember, di Toadlane, Rochdale, Inggris yang kemudian dikenal sebagai Pionner Rochdale, para perintis koperasi konsumen pertama di dunia ini. Di luar sektor koperasi konsumsi, ada rintisan-rintisan jenis koperasi lain yang hingga saat ini memegang peranan penting. Misalnya Raiffisien seorang Walikota Flankesfare di Jerman dimana dia mengambil inisiatif mendorong petani-petani di sekitar kota untuk membentuk koperasi kredit. Schulze Delitzcsh, seorang Hakim yang mengambil inisiatif serupa dengan memberi modal awal bagi berdirinya koperasi kredit (Volkbank) di Jerman. Alfonso Desjandin, seorang wartawan terkemuka dan juga seorang anggota parlemen yang aktif membantu koperasi kredit di Kanada. Kemudian E.A. Filene, seorang pedagang kaya yang dengan caranya sendiri menunjukan keberpihakkanya pada orang kecil dan usaha kecil melalui pendidikan pengorganisasian yang kemudian ia namakan "Credit Union" atau kumpulan orang-orang yang saling percaya di Madison, Wiconsin, Amerika. Para 
perintis-perintis koperasi tersebut telah pula memberikan satu landasan ide, etika dan prinsip dasar yang kokoh bagi para penerus-penerusnya yang kemudian kita kenal sebagai nilai-nilai dan prinsip koperasi sebagai identitas koperasi dunia. Suatu pedoman terutama untuk menentukan strategi dan sebagai alat ukur dalam pencapaian komunitas atau organisasi secara bertahap dan berkelanjutan menuju sistem masyarakat partisipatif yang berkeadilan sebagaimana dicita-citakan oleh koperasi awal.

Koperasi memang produk barat, tapi sebagai suara kemanusiaan terus mengalir ke seluruh penjuru dunia dan sedikit banyak telah mampu membuktikan dirinya sebagai gerakan yang efektif dalam jalan yang damai. Motif koperasi ini jelas, secara ideologis berusaha menciptakan tatanan sosial masyarakat yang lebih berperikemanusiaan dan berkeadilan melalui jalan demokrasi partisipatif. Sementara itu dalam alasan praktisnya juga kongkrit, dimana dengan membentuk atau bergabung bersama di koperasi, manfaat-manfaat dari barang atau jasa dapat diperoleh, diproduksi atau di pasarkan lebih baik daripada di salurkan melalui saluran swasta kapitalis atau negara.

Orientasi yang berbeda ini juga terlihat dari kemampuan koperasi untuk membangun sistem yang memang tidak hanya dapat dilihat dalam dimensi mikro organisasi saja, atau sebagai bangun perusahaan saja. Koperasi sebagai sistem nilai (value system)memiliki dimensi yang luas baik secara makro ideologi, mikro organisasi, sebagai wahana individualitas berikut sebagai bagian penting dari gerakan perubahan sosial (social change movement). Secara makro ideologi, koperasi bebicara tentang ideologi, sistem sosial ekonomi, politik (strategi) pembangunan, kebijakan. Secara mikro organisasi berbicara mengenai perusahaan, profesionalisme dan pengaturan/manajemen. Sebagai wahana idividualita koperasi bergerak dalam fungsinya untuk meningkatkan harga diri. Sebagai movement ingin mewujudkan nilai-nilai keadilan dan demokrasi partisipatorik.

Koperasi adalah bagunan sistem yang menginginkan terjadinya keadilan sosial ekonomi secara partisipatif. Dimana kita pahami bahwa suatu sistem ekonomi tentu tidak hanya sebuah perangkat institusional untuk memuaskan keinginan dan kebutuhan yang ada, tapi juga sebagai suatu cara untuk menciptakan dan membentuk keinginan-keinginan di masa depan. Bagaimana manusia bekerja bersama-sama untuk memuaskan keinginan mereka saat ini bisa mempengaruhi keinginan yang akan mereka punyai kemudian, menjadi orang seperti apa kemudian. Karenanya harus di landaskan pada moral politik dan ekonomi. Mereka tidak hanya harus adil tapi juga disusun supaya mendorong sifat baik keadilan dalam mereka yang ambil bagian di dalamnya (Rawls, 1995). Koperasi sebagai alternatif dari sistem yang ada, memiliki relevansi yang kuat untuk mewujudkan citacitanya sebagai bangunan sistem sosial ekonomi yang memungkinkan 
terwujudnya keadilan. Sebab sesungguhnya tidak ada keadilan tanpa hidup bersama, dan tidak ada hidup bersama tanpa keadilan.

Koperasi adalah organisasi orang-orang yang dilandaskan pada prinsip yang jelas, kerjasama adalah kuncinya, bagi si kaya maupun si miskin, tua atau muda, laki-laki atau perempuan. Siapapun mereka, apakah sebagai individu-individu atau merupakan representasi sebuah kelompok dan bagi mereka segala usahanya di tujukan bagi tegaknya keadilan, demokrasi partisipatif adalah afiliasi koperasi. Tidak ada sifat permusuhan bagi koperasi terhadap siapapun. Tapi koperasi dengan caranya sendiri sudah barang tentu menolak segala bentuk ekspolitasi, penindasan, pembodohan, pemelaratan, dsb. Kezaliman adalah musuh abadi koperasi.

Sebagai bangunan mikro organisasi, perusahaan koperasi adalah bangunan perusahaan yang futuristik karena di dalamnya dijamin adanya akses sumberdaya, proses serta pembagian hasilnya secara adil dan merata dalam sistem economic patrone refund. Di dalam bangun perusahaan koperasi segala hal yang menyangkut urusan privat (res-privata) dan urusan publik (res-publika) mendapatkan tempat yang seimbang. Konsekwensi sosial dan juga hak-hak privat dijamin dalam sistem koperasi. Melalui perusahaan koperasi, semangat kewirausahaan sosial (social entrepreneurship) dibangun dan profesionalisme berpengabdian (vocational) koperasi diajarkan.

Dalam dimensinya sebagai wahana individualita, koperasi memegang peran penting bagi terwujudnya masyarakat yang mandiri dan berkepribadian. Bagi masyarakat koperasi, struktur masyarakat yang pincang atas sebab dominasi, hegemoni, dikikis dengan selalu mengasah kepercayaan diri bagi tiap-tiap individu melalui model pendidikan koperasi. Ruang-ruang pendidikan koperasi adalah tempat belajar yang mencerdaskan dan memberikan inspirasi bagi munculnya pembaharuanpembaharuan sosial di dalam struktur masyarakat.

Seperti halnya sistem nilai yang lain, koperasi membutuhkan sayap pergerakan, yaitu sebuah perjuangan bagi terwujudnya nilai-nilai universal seperti keadilan, solidaritas, demokrasi, kejujuran/transparansi, dan lainlain yang merupakan nilai-nilai virtus yang selayaknya juga diperjuangkan bagi kita semua yang mencintai tatanan hidup yang lebih baik menuju masyarakat global yang lebih berkemanusian dan berkeadilan (humanistic global community). Karena sejarah pemikiran demikian maka koperasi bukanlah sub-sistem dari sistem mainstream yang ada. Kalau persoalannya dia dapat bertahan di dalam sistem apapun, itu karena sifat koperasi yang cukup kenyal. Tapi koperasi adalah memiliki identitasnya sendiri, dan karena identitasnya tersebut maka koperasi ada.

Perjalanan panjang perkoperasian di berbagai belahan dunia menunjukkan bahwa koperasi sebagai alternatif ternyata cukup efektif dalam rangka untuk meningkatkan kesejahteraan dan arti keadilan sosial 
ekonomi bagi masyarakat. Hingga saat ini ada 224 anggota organisasi tingkat nasional maupun internasional yang menjadi anggota International Co-operative Alliance(ICA)sebagai organisasi gerakan koperasi di tingkat global. Koperasi meliputi 1 milyard lebih anggota perorangan, dan 223 anggota perwakilan koperasi nasional dan organisasi internasional. Di Perancis: Credit Mutual, Banque Populaire, Credit Agricole menjadi bank kelas dunia. Di Swiss Migros dan Suisse menguasai 91\% pasar ritel. Desjardin Credit Union dan Credit Mutual adalah bank of the year tahun 2010 di Kanada dan Perancis. Kurang lebih 3 miliar orang atau separuh dari jumlah penduduk dunia mendapat pekerjaan dari perluasan usaha-usaha koperasi.

Di Kolombia menguasai $24 \%$ jasa kesehatan, di Swedia menyediakan layanan pribadi sehari-hari 6o\%, di Amerika 13\% jasa layanan listrik dan memiliki separuh saluran distribusi listrik. Di sektor keuangan koperasi melayani 326 juta orang nasabah, 80-99 persen produksi susu di Norwegia, Selandia Baru dan Amerika Serikat, 71 persen untuk produksi perikanan di Korea Selatan dan 40 persen sektor pertanian di Brasil. Lebih dari 40\% penduduk USA adalah anggota koperasi, 25\% penduduk Iran, di Kenya menyumbang PDB sebesar 45\%, New Zealand 22\%. Koperasi menyediakan 100 juta pekerjaan yang berarti 20\% lebih besar dari Multinational Corporate. Sepuluh negara dengan ranking Global Competitiveness Indexs Tahun 2010-2011 adalah penyumbang koperasi kelas dunia dalam daftar ICA-Global3oo. Tiga ratus Koperasi kelas dunia memiliki turnover bussiness lebih besar dari Kanada (di atas 1 triliun dollar Amerika). Pada tanggal 2009, dalam Rapat Umum PBB menetapkan tahun 2011 sebagai tahun koperasi internasional (IYC, 2012).

Ada suatu fenomena yang menarik bahwa 10 negara-negara yang disebut sebagai pemilik Competitiveness Rangking Index 2010-2011 terbaik oleh World Economic Forum (WEF) adalah negara-negara dimana koperasi disana mampu menunjukkan dirinya sebagai pemberi manfaat-manfaat besar bagi kehidupan yang lebih baik bagi masyarakat. Seperti Swiss, Findland, Sweden, Denmark, Singapore, USA, Jepang, Jerman, Belanda, Ingrish. Ini fakta bahwa koperasi telah mampu membuktikan dirinya sebagai countervailing dari sistem kapitalisme itu.

\section{PELUANG KOPERASI DALAM ISU LAYANAN PUBLIK}

Tuntutan masyarakat atas demokratisasi bentuk-bentuk layanan publik terlihat terus mengejala seiring dengan bergulirnya wacana demokrasi. Institusi-institusi layanan publik seperti kesehatan, pendidikan, pengaman sosial, transportasi, air dll dituntut adanya transparansi, keterlibatan, dan juga pembiayaan yang murah bahkan bila dimungkinkan 
malah gratis seperti dalam fungsi layanan utama dalam sektor pendidikan dan kesehatan.

Dalam penyelenggaraan layanan publik yang demokratis, setidaknya harus memenuhi beberapa syarat sebagai berikut ; berorientasi pada pelayanan terbaik (non-profit), ada partisipasi langsung masyarakat dalam pengambilan kebijakan dan pengawasan, dijamin adanya kesetaraan dalam pengelolaanya, perlindungan dana kembali (economic patrone refund) dari yang dibayarkan masyarakat, pertanggungjawaban pada masyarakat, transparansi dan akuntabilitas pengelolaan administrasi dan keuangan, kesetaraan(non-diskriminasi) dan keberpihakan pada yang lemah.

Sampai saat ini kita memang belum punya sebuah pilihan yang mantap dan mau dibawa kemana sebetulnya visi dari fungsi-fungsi layanan publik kita ini. Ada kecenderungan bahwa fungsi-fungsi layanan publik kita yang semula negara sentris akan dibawa kearah proses kapitalistik melalui istilah privatisasi (swastanisasi) dan atau dibolak-balik kembali ke sistem state dengan jargon nasionalisme. Gejala ini terlihat dari ketidakmenentuan proses privatisasi dan nasionalisasi kembali beberapa fungsi layanan publik yang diselenggarakan dalam model BUMN.

Di republik ini kita kenal dengan dua model Badan Hukum yang merupakan subyek hukum yang diciptakan oleh hukum. Pertama, Badan Hukum Publik seperti pemerintah pusat, pemerintah daerah dan pemerintah kota. Kedua adalah Badan Hukum Privat/Perdata seperti perseroan, yayasan, BUMN (Badan Usaha Milik Negara), perhimpunan, BHP (Badan Hukum Pendidikan), perhimpunan, perkumpulan, koperasi dll. Agar demokrasi berjalan, penyelenggaraan layanan publik dapat menggunakan bentuk-bentuk badan hukum perdata yang diakui oleh negara.

Kalau kita coba konstruksikan dari model pengelolaan dari badanbadan hukum perdata/Privat yang telah kita miliki selama ini maka ada tiga jenis. Pertama model pengelolaan oleh negara (pemerintah) murni. Kedua model swasta kapitalistis/feodalistik. Ketiga adalah model pengelolaan dari, oleh dan untuk masyarakat murni secara kolektif.

Pertama model kepemilikan/pengelolaan oleh negara. Di negara kita berbentuk BUMN, BHMN (Badan hukum Milik Negara), perusahaan jawatan, dan bahkan perseroan. Model kepemilikanya adalah oleh Pemerintah, dibiayai oleh pemerintah dan dikelola oleh Pemerintah dengan status karyawanya sebagai pegawai semi negeri (public servant). Landasan filosofinya karena pemerintah dipilih oleh rakyat dan melekat padanya otoritas tunggal bagi pengaturan tata hubungan sosial ekonomi warganya. Negara (baca: pemerintah) menjadi memiliki hak legitimasi mutlak bagi penyelenggaraan layanan publik atas biaya dari sumber-sumber pajak dan utang negara yang dibayarkan dan ditanggung oleh masyarakat. 
Badan Hukum negara ini karena otoritas yang melekat padanya sangat kuat maka bisa menjadi kehilangan nafasnya untuk memberikan layanan yang terbaik kepada masyarakat dan seringkali malah berperilaku sebagai majikan atas asset-aset yang dikuasainya. Karena masyarakat adalah hanya sebagai obyek dari pelayanan, maka masyarakat tidak banyak terlibat. Termasuk dalam hal penjualan-penjualan asset negara ke pasar (privatisasi). Negara menjadi semau-maunya karena negara punya sifat memaksa. Tuntutan, keluhan masyarakat laksana anjing menggonggong kafilah berlalu.

Hampir setiap hari kita disuguhi berita tentang bobroknya bentuk layanan publik yang dikelola oleh negara ini. Selain birokratif, seringkali banyak pemborosan yang dilakukan oleh organisasi layanan publik model negara ini dengan istilah yang sangat permisif inefisiensi yang bebannya ditanggung oleh masyarakat sebagai pembayar pajak. Cerita privatisasi (swastanisasi) adalah drama pengalihan yang skenario dan aktornya ditentukan sendiri oleh Pemerintah. BUMN ini diorientasikan juga oleh Pemerintah kita dalam rangka untuk mencari keuntungan (profit making). Bahkan bisa dijual ke swasta kapitalis dengan dalih untuk menutup defisit anggaaran.

Kedua, model kepemilikan swasta kapitalistik dan feodalistik. Bentuknya bisa seperti perseroan (PT), CV, Firma, UD, atau Yayasan. Model kepemilikannya adalah orang perorangan dan atau beberapa gelintir orang yang memiliki modal. Diinvestasi dan dibiayai oleh mereka para pemilik modalnya dan dalam proses pengaturanya digunakan prinsip otoritas dominan pada pemilik saham terbesar dalam prinsip satu saham satu suara (one share one vote) atau otoritas pendiri dan pengurus pada bentuk Yayasan.

Filosofinya ditekankan pada pemikiran bahwa apabila layanan publik diserahkan kepada swasta kapitalis/feodalistik model Perseroan atau Yayasan ini maka yang akan terjadi adalah fungsi layanan publik akan mendapatkan layanan prima karena akan terjadi efisiensi karena persaingan yang terjadi di pasar. Motifnya adalah untuk pencarian keuntungan(profit oriented). Pada masa kompetisi (persaingan) mungkin masyarakat akan banyak diuntungkan dengan harga murah, namun celakanya, karena kepemilikanya adalah bersifat perorangan atau oleh sekelompok orang yang memiliki modal besar, pada saat kepemilikan modal mereka menjadi akumulatif, maka yang muncul adalah monopoli di pasar itu sendiri. Konsep layanan publik yang dikelola oleh swasta kapitalis ini akan memunculkan tiran minoritas bagi kepentingan layanan moyoritas masyarakat.

Ketiga, model kepemilikan masyarakat kolektif. Kepemilikan atau pengelolaan dari model ini sebetulnya di Indonesia sudah kita kenal dengan model badan hukum koperasi. Investasinya dari masyarakat dan juga dapat 
dari pemerintah, dikelola oleh masyarakat dan ditujukan untuk melayani masyarakat. Prinsip kepemilikan dan otoritas pengambilan keputusanya adalah satu orang satu suara (one man one vote) karena berbeda dari model layanan sebelumnya, koperasi ini adalah bentuk dari perkumpulan orang (people base association) dan bukan perkumpulan modal (capital base association). Jumlah kepemilikan modal didalam sistem koperasi ini tidak dijadikan sebagai penentu, betapapun modal dianggap penting, didalam koperasi hanya sebagai alat bantu untuk mencapai tujuan manfaat(benefit). Tujuan dari koperasi ini tidak bagi akumulasi keuntungan (profit oriented)tapi diorientasikan kepada fungsi peningkatan manfaat layanan (benefit oriented). Koperasi dalam layanannya juga bukan seperti dalam yang ada pada model yayasan yang penekananya adalah karitas.

Di negara lain seperti negara maju seperti Amerika Serikat, Kanada, Eropa Barat, Jepang, negara-negara skandinavia, Singapore dll hingga di negara-negara model sosialis baru seperti di Bolivia, dan Venesuela, model koperasi pemangku kepentingan (multistakeholder co-operative) ini juga digunakan sebagai alternatif badan hukum layanan publiknya. Seperti misalnya Amerika Serikat dalam pengelolaan infrastuktur listriknya dipedesaan, dan Bolivia dalam pengelolaan rumah sakitnya. Konsep Koperasi pemangku kepentingan (co-operative multistakeholder) adalah bentuk koperasi yang melibatkan seluruh komponen baik perwakilan pemerintah, pegawainya, masyarakat pengguna jasanya.

\section{KOPERASI DALAM MEMPERTINGGI MODAL SOSIAL}

Membicarakan modal sosial (social capital) pada intinya kita sedang mempelajari bagaimana sebuah masyarakat bekerjasama membangun suatu jaringan untuk mencapai tujuan bersama untuk memperbaiki kualitas kehidupan. Bagaimana sebuah masyarakat membentuk pola interaksi antar individu dalam kelompok dan antar kelompok dengan ruang perhatian pada jaringan sosial, norma, nilai dan kepercayaan antar sesama yang lahir dari sebuah kelompok adalah merupakan dimensi utama dalam kajian modal sosial. Sebagaimana dinyatakan oleh Fukuyama (1995) modal sosial ini memiliki dimensi yang luas menyangkut segala sesuatu yang membuat masyarakat bersekutu untuk mencapai tujuan bersama atas dasar kebersamaan, dan didalamnya diikat oleh nilai-nilai dan norma-norma yang tumbuh dan dipatuhi.

Koperasi, sebagai sebuah gerakan perubahan sosial yang menekankan pada fungsi pembangunan yang berpusat pada manusia (human centre development) sudah barang tentu menjadikan modal sosial ini sebagai sebuah poin penting untuk mencapai tujuan-tujuanya disamping modal material dan modal kultural. Bahkan dapat dikatakan, tidak ada tugas yang lebih penting dari gerakan koperasi ini kecuali memupuk dan 
mempertinggi arti dari modal sosial ini untuk kepentingan kemajuan peradaban sebuah masyarakat. Modal sosial yang didorong oleh sikap saling memperhatikan, saling memberi dan menerima, sikap partisipatif, dan saling percaya dan mempercayai ini juga telah dijalankan oleh koperasi sejak awal mula kelahiranya. Koperasi sebagai gerakan perubahan sosial (social change movement) memiliki tujuan-tujuan penting dan menekankan pelaksanaan prinsip-prinsipnya dalam basis nilai-nilai utama yang penting untuk mempertinggi modal sosial (social capital). Koperasi sejak satu setengah abad silam lebih selalu berusaha untuk memperjuangkan nilainilai: menolong diri sendiri, tanggungjawab sendiri,demokrasi, persamaan, keadilan dan solidaritas. Mengikuti tradisi para pendirinya anggota-anggota koperasi menjunjung tinggi nilai-nilai etis dari kejujuran, keterbukaan, tanggungjawab sosial serta kepedulian terhadap orang lain.

Peranan koperasi ini menjadi semakin strategis karena didalam koperasi tidak hanya menekankan pada aspek-aspek pelaksanaan kebajikan sosial (social virtues) namun lebih itu, sebagaimana telah menjadi ciri gerakan inklusif koperasi, koperasi memiliki peranan penting untuk mengangkat nilai-nilai kebajikan sosial tersebut ke ranah publik (public sphere) yang lebih luas dalam pola jejaring kerjasama lintas suku, agama, ras, golongan, interes politik, maupun stratifikasi sosial apapun. Kaya dan miskin, tua maupun muda, laki-laki maupun perempuan dapat pengakuan yang sama (equal) dalam konsep keanggotaan yang sukarela dan terbuka (voluntary and open membership) dalam koperasi. Bisa jadi, berbagai koperasi di berbagai belahan bumi ini keberadaanya tak lepas dari dorongan para politisi, kaum agamawan, tokoh-tokoh masyarakat dan lain sebagainya, namun satu hal yang menjadi ciri khas koperasi adalah bahwa koperasi itu tak dapat diklaim sebagai sebuah gerakan sektarian, primordial atau juga gerakan tidak religius atau atheisme sekalipun, karena klaim sempit demikian telah meruntuhkan dirinya sendiri untuk dapat layak disebut sebagai kopeasi sejati.

Literatur-literatur tentang modal sosial menyebutkan, ada beberapa unsur pokok dalam modal sosial, diantaranya adalah: Partisipasi dalam jaringan, resiprositas (keimbal-balikan), trust (rasa percaya mempercayai), norma-norma sosial, nilai-nilai, dan tindakkan proaktif. Dalam dimensi mikro organisasi, koperasi sebagai organsiasi modern yang berorientasi pada tujuan dibentuk oleh unsur-unsur pokok modal sosial ini. Sebagaimana telah ditegaskan dalam indentitas koperasi internasional (International Co-operative Identity Statement-ICIS) koperasi adalah merupakan sebuah perkumpulan orang yang otonom dari orang-orang yang bersatu secara sukarela untuk memenuhi kebutuhan-kebutuhan dan aspirasi ekonomi, sosial dan budaya bersama melalui perusahaan yang mereka miliki bersama dan mereka kendalikan secara demokratis. Dalam praktek, koperasi-koperasi sejati dalam operasionalisasinya dilandaskan 
pada prinsip-prinsip: keanggotaan sukarela dan terbuka, pengendalian oleh anggota secara demokratis, partisipasi ekonomis anggota, otonomi dan kebebasan, pendidikan-pelatihan dan informasi, kerjasama antar koperasi serta kepedulian terhadap komunitas. Koperasi-koperasi sejati, dalam upaya mencapai tujuanya selalu diusahakan untuk melakukan penggiatan kesadaran (conciousness) anggota untuk aktif berpartisipasi dalam berbagai aktifitas organisasi.

Jaringan kerja koperasi yang meliputi segala sektor hanya akan efektif bilamana disokong oleh partisipasi aktif para anggota-anggotanya. Suatu organisasi dapat disebut koperasi bilamana didalamnya terdapat peranperan aktif anggotanya dalam proses bisnis dan sosial, ada peran-peran aktif anggotanya dalam kegiatan pengawasan langsung dan sebagainya-dan sebagainya. Koperasi sejati itu bekerja dalam kerangka efisiensi kolektif (collective efficiency) dari anggota-anggotanya dan selalu berusaha semaksimal mungkin untuk memperluas keanggotaanya tanpa diskriminasi apapun.

Dalam praktek terbaik (best practicies) koperasi diberbagai belahan dunia, efektifitas koperasi untuk membangun kesadaran partisipatif anggota-anggotanya ini lebih banyak ditopang oleh jalur pendidikan koperasi yang tertanam secara masif pada anggota-anggotanya. Setidaktidaknya mereka musti paham apa yang disebut sebagai organisasi atau perusahaan koperasi, sejarah, nilai-nilai serta prinsip-prinsip utamanya. Koperasi dalam fungsi pendidikanya adalah merupakan "sekolah demokrasi” yang efektif bagi semua.

Dalam sebuah pola hubungan tradisional, bisa jadi sebuah jaringan itu terbentuk oleh suatu dasar kesamaan garis keturunan, pengalaman sosial turun temurun, atau kesamaan kepercayaan dalam sebuah dimensi yang religius. Berbeda dengan koperasi, orientasi koperasi yang menekankan pada aspek pencapaian tujuan bersama membuka diri bagi siapapun untuk turut berpartisipasi dalam koperasi. Inklusifitas koperasi inilah yang pada akhirnya bermakna bagi proses pengkayaan modal sosial yang ada di masyarakat dengan rentang jaringan yang lebih luas.

Dalam hubunganya dengan unsur resiprositas/keimbal-balikan, telah menjadi ajaran idiil koperasi dari sejak awal mula untuk saling mempedulikan antar satu anggota dengan anggota yang lain. Berangkat dari perasaan solidaritas diantara orang-orang yang ada didalamnya, koperasi berusaha untuk saling bantu-binantu antar satu dengan lainya. Nilai soldaritas koperasi ini terlihat dalam praktek kehidupan para anggotaanggotanya dalam sebuah prinsip "kamu susah saya bantu dan saya susah kamu bantu”. Sebuah ciri solidarita setara koperasi dan bukan karitas yang mendekte yang banyak dipraktekkan oleh korporasi atau lembaga-lembaga karitas. Dalam operasionalisasinya, bentuk kepedulian ini adalah inheren dalam aktivitas koperasi. Salah satunya yang dapat kita lihat sebagai 
perbedaan yang nyata adalah bahwa bisnis dalam koperasi itu adalah merupakan bentuk pelaksanaan tanggungjawab sosial dan bukan sebagai entitas yang terpisah sebagaimana dapat kita lihat dalam model proyek tanggungjawab korporasi (corporate social responsibility) dalam perusahaan yang kapitalistik saat ini. Dalam kaitanya dengan unsur trust atau sikap saling percaya mempercayai ini terlihat sangat nyata dalam praktek koperasi. Terutama sekali dapat kita lihat dari praktek para anggotaanggota koperasi kredit (credit union) yang juga diartikan sebagai "persatuan kepercayaan" ini. Dalam konsep koperasi kredit yang anggotanya telah mencapai 177 juta orang diseluruh dunia ini dalam praktek selalu mengedepankan "kepercayaan pada orang lain" ketimbang sebuah dasar atas jaminan atau "boroug". Koperasi selalu mengedepankan sisi kepercayaan pada seseorang, sehingga seseorang tersebut diharapkan selalu berusaha untuk mencapai sebuah capaian untuk meningkatakan kapasitas dirinya agar selalu memiliki karakter "untuk dipercaya". Oleh karena itu, dalam kehidupan perkoperasian, seseorang itu tidak hanya bisa dipercaya, tapi dalam sistem kopeasi seseorang itu juga dituntut untuk menunjukkan sikap-sikap yang terpercaya.

Modal sosial dikoperasi adalah merupakan modal utama dan keberadaanya adalah merupakan alasan adanya (raison d'etre) koperasi. Dalam posisinya yang kunci ini, maka ada suatu keharusan bagi sebuah organisasi koperasi untuk terus meningkatkan modal sosial yang ada didalamnya. Dalam kaitanya, sebuah koperasi hanya akan berhasil masif dan efektif apabila menjadikan organisasinya untuk berorientasi keluar (outward looking) dalam membangun jaringannya.

\section{PENUTUP}

Sebuah fakta bahwa, saat ini koperasi telah menunjukkan kekuatanya sebagai sebuah pembaharuan peradaban dengan tekanan pada sifat sukarela dari pembentukannya untuk memenuhi kebutuhan ekonomi, sosial dan budaya yang mana telah memberikan arti yang lebih besar dan kepercayaan untuk demokrasi dan keadilan. Terbuka bagi semua warga negara untuk berpartisipasi, terlepas dari suku, agama, ras golongan maupun interes politik.

Koperasi memberikan jaminan bagi setiap individu untuk bebas dari ketidakadilan, ketidaksetaraan, pengangguran, jerat utang, tidak efisiennya penggunaan modal sosial dan keuangan, penurunan produktivitas, serta anomi yang disebabkan oleh sistem kapitalisme.

Koperasi, bagaimanapun, tidak hanya merupakan tempat kepemilikan dan keputusan bersama, tetapi karena kepemilikan ekspansif mereka dan niat kolaboratif, mereka menawarkan kemungkinan lebih banyak pekerjaan. Dengan kata lain, jenis usaha yang dipilih dan jenis kepemilikan, dan model 
produksi yang sesuai, untuk sebagian besar, menentukan jenis perekonomian yang dapat dibangun dan bagaimana hal ini dapat melayani masyarakat secara luas.

Ekonomi kapitalistik dan sosialistik yang dicampur telah terbukti mengecewakan, karena sejumlah besar orang terus hidup dalam kemiskinan dan kemelaratan, hidup di bawah tekanan yang besar dan kekecewaan. Pekerja juga jarang mendapatkan imbalan yang layak dari pekerjaan mereka. Dengan kegagalan kapitalisme dan komunisme, beberapa sekarang mendukung demokrasi ekonomi berdasarkan prinsip koperasi. Ini berarti, bahwa sejauh mungkin, keputusan-keputusan ekonomi yang mempengaruhi kehidupan rakyat harus dibuat oleh mereka sendiri. Pada dasarnya, demokrasi yang lebih partisipatif, di mana pertumbuhan ekonomi akan menguntungkan sejumlah besar warga negara.

Sekarang sangat jelas bahwa pertumbuhan saja tidak cukup untuk mengurangi kemiskinan dan ketidaksetaraan. Baik itu dinegara maju maupun yang berkembang maupun terbelakang. Kualitas pertumbuhan harus memenuhi prinsip keadilan sehingga sejumlah besar pekerja berpartisipasi dalam semua aspek pertumbuhan ekonomi. Pada saat yang sama, filosofi koperasi diharapkan juga bertindak sebagai rem keserakahan berlebihan dalam konsumsi serta modernisasi jaman. Pertanyaan kesejahteraan dan kebutuhan sosial ekonomi lainya, seperti kesehatan, dan asuransi, akan lebih baik bila diusahakan dalam sistem kolektif koperasi. Jaminan sosial, tabungan dan keuangan mikro adalah kegiatan normal dari koperasi dengan kepentingan tidak hanya untuk keuntungan tapi untuk kesejahteraan rakyat dan ini adalah apa koperasi telah sediakan.

Satu fakta kesesuaian koperasi adalah bahwa selama beberapa dekade terakhir ketika negara-negara di banyak daerah, seperti di Amerika Latin dan Asia, telah mengalami keruntuhan sistem keuangan mereka, dan lebih saat ini ketika semua ekonomi kapitalistik yang mendalam dalam krisis ekonomi, koperasi-menjalankan bisnis dan industri yang sebagian besar tetap tak terkena dampaknya. Diseluruh penjuru dunia, koperasi ketika krisis saat ini justru semakin menunjukkan pertumbuhannya.

Pada dasarnya, koperasi menawarkan sebuah arah baru bagi kemanusiaan, atas gagasan keadilan ekonomi dan sosial yang lebih adil dari sistem swasta kapitalis. Sistem kekenyalan kerjasama koperasi juga merupakan tantangan dalam rangka mengintegrasikan masyarakat agar pembangunan ini terasa lebih bermartabat dan berkelanjutan.

\section{DAFTAR PUSTAKA}

Derber, Charles. 200o. Corporation Nation: How Corporations are Taking Over Our Lives and What We Can Do about It. New York: St. Martin's Griffin. 
Fukuyama, Francis. 1995. Trust: The Social Virtues and The Creation of Prosperity. New York: Free Press.

Keohane, Robert O. dan Joseph S. Nye. 200o. Power and Interdependence. New York: Longman.

Munkner, Hans H. 1995. Chances of Co-operatives in the Future: Contribution to the International Co-operative Alliance Centennial, 18951995. Marburg: Marburg Consult für Selbsthilfeförderung.

Ohmae, Kenichi. 2005. The Next Global Stage: Tantangan dan Peluang di Dunia yang Tidak Mengenal Batas Kewilayahan. Jakarta: Indeks.

Prakash, Aseem dan Jeffrey A. Hart. 1999. Globalization and Governance. London: Routledge.

Rawls, John. 1995. A Theory of Justice. New York: Oxford University Press.

Robinson, William I. 2004. A Theory of Global Capitalism: Production, Class, and State in a Transnational World. Baltimore: The John Hopkins University Press.

Stiglitz, Joseph E. 2003. Globalization and its Discontents. New York: W.W. Norton Company.

Stiglitz, Joseph E. 2007. Making Globalization Work: Menyiasati Globalisasi, Menuju Dunia yang Lebih Adil. Bandung: Mizan. 